\title{
Where Are the Accounting Professors?
}

Jui-Chin Chang, (Email: cjchang40@yahoo.com), Morgan State University

Huey-Lian Sun, (Email: hsun@jewel.morgan.edu), Morgan State University

\begin{abstract}
Accounting education is facing a crisis of shortage of accounting faculty. This study discusses the reasons behind the shortage and offers suggestions to increase the supply of accounting faculty. Our suggestions are as followings. First, educators should begin promoting accounting academia as one of the career choices to undergraduate and graduate students. Second, schools should provide adequate financial support to Ph.D. students. Third, academic administers should encourage faculty's involvement in mentoring Ph.D. students. Finally, the tenure and promotion system needs to be reevaluated to facilitate success in faculty development.
\end{abstract}

ust before Enron, WorldCom and other accounting scandals, Albrecht and Sack (2000) cast doubts on the future of accounting education. They quoted the AICPA's supply-and-demand reports to support their allegation that fewer and less qualified students were choosing accounting as a major. They argued that students perceived accountants to be incompatible with the creative, rewarding and people-oriented careers that many students envisioned for themselves. They also contributed the problem of declining enrollment to poorly designed accounting programs that were not attractive to students and did not meet the demand of accounting professionals. Even before the report of Albrecht and Sack (2000), many institutions and studies have devoted resources to increase accounting enrollment in order to meet the demand of the accounting profession and to survive. ${ }^{1,2}$ They often emphasized on attracting the best and brightest students into the accounting profession. However, they failed to recognize that inspiring and passionate professors are the keys to attract the best and brightest students. Unfortunately, the accounting education in recent years has encountered a serious shortage of qualified faculty. The shortage came at a time when studies have just reported a stable increase in accounting enrollment. $^{3}$ In the near future, accounting education might face a crisis that there are not enough qualified accounting faculty to teach the best and brightest students attracted to the programs.

Some studies have provided insight on the shortage of qualified accounting faculty from the demand and supply of future faculty. Carpenter and Robin (2004) reported that the doctoral program output in accounting has declined to 110 in 2002 when it compared with an average approximately 200 per year in the late 1980s through mid-1990s. Gullapalli (2004) reported that the number of accounting faculty openings was more than twice in the number of submitted resumes in 2002. The Association to Advance Collegiate Schools of Business (AACSB) estimated the faculty shortage including accounting in the United States to reach 1,142 individuals by 2008, and 2,419 by 2013. ${ }^{4}$ Plumlee, Kachelmeier, Madeo, Pratt, and Drull (2006) reported similar prediction of an overall shortage of accounting faculty.

\footnotetext{
${ }^{1}$ For instance, in 1994, the Institute of Management Accountants (IMA) and the Financial Executives Institute (FEI) sought for What Corporate America Wants in Entry-Level Accountant from the "customer perspective." In 1998, the American Accounting Association (AAA) urged each institution to define its market niche in order to build new curricula in the high priority areas. The IMA's 1999 Counting More, Counting Less outlined the transformations in the management accounting profession.

2 Bedford Commission (1986) stated that accounting education was not meeting the needs of changing profession (Friedlan, 1995). Inman, Wenzler, and Wickert (1989) warned that the accounting majors did not attract the right type of students. The Accounting Education Change Commission (AECC) was appointed by the American Accounting Association and supported by the Big Eight (then) public accounting firms in 1989 when the White Paper: Perspectives on Education was published. Its Position Statement Number One addressed the objectives of accounting.

3 Titard, Braun and Meyer (2004) and Gullapalli (2004) reported that there was contrary evidence to the previous concern about losing accounting students due to the accounting scandals. In fact, students gained a deeper understanding of accounting matters and its implication of the profession after the Sarbanes-Oxley Act and the economy downturn.

${ }^{4}$ Rayburn, J. (2005). Retrieved from http://aaahq.org/AM2005/menu.htm/2005_Rayburn.ppt.
} 
The purpose of this study is to examine reasons for the shortage of accounting faculty from both the demand and supply perspectives and offer suggestions to reverse the trend of shortage with emphasis on increasing the supply of qualified accounting faculty.

\section{SHORTAGE OF ACCOUNTING FACULTY: FROM THE DEMAND PERSPECTIVE}

There are many factors which induced an increasing demand for accounting faculty. First, although critics has criticized the 150-hour requirement that hindered the enrollment of undergraduates, it could result in an increase in the number of accounting courses taught, and subsequently an increase in the demand for accounting faculty (Campbell et al, 1990). Many universities now offer 5-year accounting programs for students to get both undergraduate and master degrees in five years to meet the 150-hour requirement. Accordingly, more accounting faculty members are needed for the additional accounting courses.

Second, the prevailing trend toward lowering teaching load may be accounted as another factor for increasing demand for accounting faculty. Many business programs emphasizing research in their tenure and tenure systems have reduced teaching load for faculty. For example, most teaching schools with moderate research requirements have three-course teaching load per semester while research oriented schools have two or less per semester for accounting faculty. The competition for new faculty makes teaching load an important determinant in the mutual selection process between faculty candidates and schools. Therefore, in order to compete for good candidates, some schools are willing to offer lower than normal teaching load to new faculty. As a result, schools have to either increase class sizes or hire more faculty members to cover all courses offered.

Third, the increasing number of business programs seeking for accreditation from the AACSB also contributes to the increasing demand for accounting faculty. To receive the AACSB accreditation, schools have to meet standards that require programs to have a substantial faculty with terminal (doctoral) degree teaching in the programs. In addition, the AACSB standards require faculty to have intellectual contributions (publications) to be academically qualified. These standards force schools seeking for AACSB accreditation to hire more qualified accounting faculty. Therefore, the demand for qualified accounting faculty has increased. According to AACSB, the number of business schools achieving the AACSB accreditation has increased from 330 in November 2000 to 530 in July 2006 (Sinning \& Dykxhoorn, 2001; AACSB). ${ }^{5}$

Finally, the retirement of current faculty who are baby boomers deepens the plight of demand for accounting faculty. Campbell, Hasselback, Hermanson, and Turner (1990) used the Hasselback faculty database and used age 65 as retirement age to study whether there would be shortage of accounting faculty for a 25 -year span from 1990 to 2014. Their results showed a severe shortage trend of accounting faculty due to the reason that the retirement rate is to be higher than the growth of replacement rate. In fact, many accounting programs now are experiencing the pressure of losing faculty who are close to their retirement age.

\section{SHORTAGE OF ACCOUNTING FACULTY: FROM THE SUPPLY PERSPECTIVE}

Several reasons have contributed to the decline in accounting Ph.D. candidates. First, academia has not been promoted as an accounting career choice. Carpenter and Robson (2004) claimed that a lack of interest in academia might be the domain reason for low enrollment in accounting Ph.D. programs. According to their study, the decline in Ph.D. program output first evident in 1995 has become a trend. Lack of interest in academia and fewer applicants are severe factors in the decline of accounting Ph.D. candidates. Unaware of academia as an accounting profession, negative perception of accounting academia, and upswing interests in other disciplines are other reasons for fewer applicants in the Ph.D. programs.

Second, high opportunity costs can hinder potential candidates. On average, it takes students four to six years beyond a master's degree to get a Ph.D. degree in accounting. The opportunity cost of current earnings and future earnings to the candidates of pursuing a Ph.D. degree can be considerable. Most schools provide financial aids to $\mathrm{Ph}$.D. students on condition that they must be full-time students. Students thus have to give up their full-time jobs to join the programs. However, many Ph.D. students perceived that the amount of financial aid is inadequate. ${ }^{6}$

${ }^{5}$ Retrieved from its web site: $\mathrm{http}: / /$ www.aacsb.edu/General/InstLists.asp?lid=2.

${ }^{6}$ Plumlee et al. (2006) found from the student survey that about one-third (one-fifth) of North American (international) students 
In addition, other highly desirable benefits such as health and life insurance are usually not available to Ph.D. students. In order to attract more students to enter Ph.D. programs, universities and schools need to find ways to reduce the opportunity costs imposed on students.

Third, the salary does not make the accounting academic career more attractive than the other disciplines. For example, accounting has lost its monetary charm to the finance discipline in recent years. According to the AACSB survey, the salaries of new hire of assistant accounting professor were $\$ 95,300$ while the salaries of new hire of assistant finance professor were $\$ 102,400$ in 2003. Even though the salary gap between finance and accounting professors narrowed down in 2005 and 2006, we probably will not see the result of increasing accounting Ph.D. students until a few years later.

Fourth, tenure-track and research related pressure and high risk of not receiving tenure are perceived to hinder students' interest in accounting academia. Tenure represents job security, academia freedom, and a career motivator. Although both teaching and research are important factors in the mission of schools, in reality, the decisive factor in tenure and promotion decisions is research (Tang \& Chamberlain, 2003). Many schools require faculty to have both quality and quantity in their publications for tenure. On average, a new accounting $\mathrm{Ph} . \mathrm{D}$. has to invest a minimum of 6 to 7 years to complete whatever work required in research, teaching and service before he/she gets tenured (Stone, 1996). Research shows that most faculty do not receive tenure at their place of original employment (Rittenburg, 1998). For a Ph.D. candidate, it is certain that more 10 years of life is at stake for her/him to pursuit accounting academia as a career.

\section{SUGGESTIONS TO INCREASE THE SUPPLY OF QUALIFIED PH.D. FACULTY}

From the above discussions of shortage of accounting faculty from both the demand and supply perspectives, we suggest that instead of curbing the increasing demand for accounting faculty, universities and schools can take actions on increasing the supply of qualified Ph.D. faculty. We offer the following suggestions.

\section{Promote Accounting Academia As One Of The Career Choices To Accounting Students}

To increase the supply of qualified accounting faculty starts with attracting qualified candidates to pursue $\mathrm{Ph}$.D. degree in accounting. This will not solve the current shortage of accounting faculty since it will take at least four to six years before we see an increase in supply. However, if we do not start promoting accounting academia as a career choice now, the shortage of qualified accounting faculty will become even worse later on. In addition to the suggestion by Plumlee et al. (2006) that AAA creates a website to provide information to attract potential students seeking accounting Ph.D. degree, we suggest schools redesign courses offered to meet the 150-hour requirement to channel undergraduate and master students into accounting Ph.D. programs. Currently, most schools have their curriculum designed to meet the 150-hour requirements for CPA examination, and they offer courses that are practitioner-oriented for firms and organizations. We suggest that school include entry-level research oriented courses in their 150-hour requirement plan to create a link between the accounting undergraduate/master programs and the Ph.D. program.

\section{Provide Adequate Financial Support To Ph.D. Students}

Even without official statistics, our experience tells us that not all Ph.D. candidates are able to complete their programs. When a student drops out of a program, it is not only the loss to the student but also a loss to the university, which has put significant investment on the student. Among all of reasons for withdrawals, the common two are financial problems and unsatisfactory academic performance. In many situations, financial problems lead to unsatisfactory academic performance which results in withdrawals. In order to increase the supply of accounting $\mathrm{Ph} . \mathrm{D}$. students, it is inevitable that universities have to provide adequate financial support to students. More importantly, faculty members have to get involved in coursework and curriculum development to help Ph.D. students succeed in the programs. The fellowships and scholarships not only can reduce the opportunity costs of pursuing a Ph.D. degree but also can create better-trained doctoral candidates if the fellowships and scholarships require Ph.D. students to be involved in doing research with faculty members.

see the financial support as inadequate. 


\section{Motivate Current Faculty To Help Ph.D. Students Succeed In Program}

The expense and cost of doctoral education are very expensive for both the schools and Ph.D. candidates. To help new Ph.D. candidates succeed in the programs, faculty involvement with students is important. Traditionally, universities place research more over teaching. Therefore, it locks up faculty to focus on doing research by self-interest to get tenure and promotion. Since teaching doctoral courses is time-consuming and supervising a dissertation takes extensive amount of time, faculty members may not feel that it is in their best interest to work with Ph.D. students. The survey by Plumlee et al. (2006) reveals that almost half of the Ph.D. students feel that their programs are too stressful. To release the students' program-related stress and help them succeed in programs, we suggest that universities provide incentives to create a mentoring atmosphere between faculty and Ph.D. students. The incentives could include release course load, stipends and grants to faculty who are mentors to Ph.D. students.

\section{Reevaluate The Tenure And Promotion System}

Most programs have a tenure and promotion system in place for motivating faculty career development and measuring faculty performance in teaching, research, and service. Although AACSB has favored mission-based standards that tie publications to schools' missions, many schools still have the tenure and promotion systems tied to research more than teaching or service. Tension exists in most campuses regarding the relative importance of teaching versus research in school missions and reward evaluations. It is time for the universities, deans and department heads to review the tenure and promotion systems to have a balanced interaction of teaching, research and service. Specific cultural changes and tenure and promotion policies are critical to facilitate faculty's success in academia and to accomplish the missions of university and department. In addition, we believe that a feasible tenure and promotion system will improve the image of the accounting academia and attract more candidates to this profession.

\section{CONCLUSION}

The continued quality of accounting education depends on the availability of qualified accounting faculty, which in turn is the way to attract the best and the brightest students into accounting. Although the enrollments of undergraduate and graduate students have turned into a positive sign, the quality of accounting education may be threaten due to the result of shortage of qualified accounting faculty. The declining quality of accounting education is evident in that many universities are coping with the shortage of faculty by hiring adjunct accounting faculty to teach. It is time for universities to build a vision with leadership to reverse the trend of decreasing supply of qualified accounting faculty.

Beginning with promoting accounting academia as a career choice to prospective Ph.D. students is a starting point to reverse the unawareness and lack of interest in accounting Ph.D. programs. Schools can use the 150-hour degree programs to expose potential Ph.D. candidates to accounting Ph.D. programs by introducing entry-level research oriented courses in the programs. Second, providing significant monetary fellowships and scholarships not only reduces the opportunity cost but also creates better-trained doctoral candidates if the fellowships and scholarship incorporate doctoral students' research with faculty's career development. Third, to help $\mathrm{Ph} . \mathrm{D}$. students succeed in the programs, accounting faculty should be inspiring and passionate in serving as mentors to students and working with them. Finally, implementing specific cultural changes and tenure and promotion policies to create a supportive academic environment will help faculty career development and improve image of the profession.

In conclusion, accounting education has recently been through the crisis of enrollment decline, and the recent increase in enrollment does not make it totally out of the crisis yet. It is time for administrators and educators to start thinking about how to increase the supply of qualified accounting faculty.

\section{REFERENCES}

1. $103^{\text {rd }}$ American Assembly, (2003). The future of the accounting profession. American Assembly Report.

2. Accounting Education Change Commission (AECC). (1990). Position statement No. One: Objectives of education for accountants. Torrence, CA: Author. 
3. Accounting Education Change Commission (AECC). (1992). Position statement No. Two: The first course in accounting. Torrence, CA: Author.

4. Albrecht, W. S. \& Sack, R. J. (2000). Accounting education: Charting the course through a perilous future. Accounting Education Series No.16. Sarasota, FL: American Accounting Association.

5. Ascierto, J. (2004). Opportunities abound for a career in accounting education. Retrieved from the web May 13, 2004. CalCPA Online, http://www.calcpa.org/community/careers/cc/articles/opportunities.html.

6. Campbell, T. L., Hasselback, J. R., Hermanson, R. H., \& Turner D. H. (1990). Retirement demand and the market of accounting doctorates. Issue in Accounting Education 5 (2), 219-221.

7. Carpenter, C. G., \& Robson G.. S. (2004). Declining doctoral output in accounting. The CPA Journal, 74 (8), 68-69.

8. Friedlan, J. M. (1995). The effects of different teaching approaches on students' perceptions of the skills needed for success in accounting courses and by practicing accountants. Issues in accounting Education, 10 (1): 47-63.

9. Gullapalli, D. (2004). Crunch This! CPAs Become the New BMOCs. Wall Street Journal, July 27: C1 \& C5.

10. Gullapalli, D. (2005). Take this job and ...file it; burdened by extra work created by the Sarbanes-Oxley Act, CPAs leave the Big Four for better life. Wall Street Journal, May 4: C1.

11. Inman, B. C., Wenzler, A., \& Wickert, P. D. (1989). Square pegs in round holes: Are accounting students well-suited to today's accounting profession? Issues in Accounting Education, 4 (2), $29-47$.

12. Plumlee, R. D., Kachelmeier, S. J., Madeo, S. A., Pratt, J. H., \& Krull G. (2006). Assessing the shortage of accounting faculty. Accounting Education, 21 (2), 113-126.

13. Read, W. J., Rama, D. V., \& Raghunandan, K. (1998). Are publication requirements for accounting faculty promotions still increasing? Issues in Accounting Education, 13 (2), 327-339.

14. Rittenberg, L. E. (1998). Hiring faculty: The "best fit" or "best athlete." Issues in Accounting Education, 13 (3), 717-719.

15. Sinning, K. E., \& Dykxhoorn, H. J. (2001). Processes implemented for AACSB accounting accreditation and the degree of faculty involvement. Issues in Accounting Education, 16 (2), 181-204.

16. Stone, D. N. (1996). Getting tenure in accounting: A personal account of learning to dance with the mountain. Issues in Accounting Education, 11 (1), 187-201.

17. Tiard, P. L., Braun R. L., \& Meyer M. J. (2004). Accounting education: Response to corporate scandals. Journal of Accountancy, 98 (5), 59-65.

18. Tang, T. L.P, \& Chamberlain M. (2003). Effects of rank, tenure, length of service, and institution on faculty attitude toward research and teaching: The case of regional state universities. Journal of Education for Business, 79 (2), 103-110. 
NOTES 